\title{
Sketching Motherhood. Maternal Representation in Contemporary Picturebooks: The Case of Spain
}

\section{Giulia De Sarlo $^{1}$ (D) Elena Guichot-Muñoz ${ }^{1}$ (D) Coral I. Hunt-Gómez ${ }^{1}$ (D)}

Accepted: 24 December 2021 / Published online: 2 February 2022

(c) The Author(s) 2022

\begin{abstract}
Although gender-role stereotypes in children's literature have been widely explored, the study of the role of mothers and their representation in picturebooks has not received much attention from the academic world, especially as far as Spain is concerned. This paper analyses a sample of seven picturebooks published in Spain over the last 7 years -all by awarded authors and widely reviewed in some of the most popular Spanish blogs on Children's and Youth Literature (CYL)-and focused on the maternal figure. It aims to provide a panoramic view of the representations of the role of the mother as a paradigm of the changes seen in Spanish society, studying the representation of her voice, emotions, and ties to other members of her family through a systemic functional-multimodal discourse analysis applied to picturebooks. The results reveal that, for the first time, the mother's voice and her right to explore her own feelings are included in her characterisation, and also, that her relationship with the rest of the family includes different aspects-children, society, work, partner, and self-care. In conclusion, the conception of motherhood as proposed to Spanish families through picturebooks seems to be finally changing,
\end{abstract}

\footnotetext{
Giulia De Sarlo holds a Ph.D. in Hispanic Philology from the University of Seville, with the 2013 Extraordinary Doctorate Award, and is a professor at that University, in the Department of Language and Literature Teaching in the Faculty of Education Sciences. Her most recent research includes encouraging reading in the infant and primary stages, linguistic and emotional development in childhood, the history of the picturebook, early literacy and attention to diversity in the teaching of language and literature.
}

\begin{abstract}
Elena Guichot-Muñoz has an M.A. and a Ph.D. in Hispanic Philology from the University of Seville. She has been teaching in the area of Language and Literature in the Faculty of Education Sciences at the University of Seville since 2011. Her most recent research focuses on the analysis of communication, literature and culture as an instrument of socio-educational mediation. She also studies interdisciplinary artistic relations as a way of integrating the humanities at the school.
\end{abstract}

Coral I. Hunt-Gómez is a lecturer at the University of Seville, Department of Language and Literature Teaching, where she teaches courses in Primary and Secondary Education. Her research foci are teacher training and new technologies applied to language learning and her recent publications can be found in Current Issues of Language Planning and in Lingua. She is also interested in new forms of writing and social media.

Extended author information available on the last page of the article 
evolving from fixed stereotypes and allowing the expression of contradictory feelings related to maternity.

Keywords Spanish children's literature $\cdot$ Picturebooks $\cdot$ Mother $\cdot$ Affects $\cdot$ Family

\section{Introduction}

In general terms, in children's picturebooks across the Western world, the figure of the mother has been analysed in isolation or, at most, in relation to or confronting the father figure (Dewitt et al., 2013). If families are conceived as systems, it is essential to examine the role of mothers in relation to the rest of the nuclear family. The birth of a first child has the potential to transform the mother's life orientation, values and the networks she has been building up to that time relating to family, work, and social spheres (Prinds et al., 2018), implying the need for a supportive and affective network during pregnancy and child-rearing (Lotero et al., 2018). As society's perception of the figure of the mother and her networks changes, there is a need for reconceptualising her individual and social identity and the burden attached to the mother's role.

In the case of Spain, until the end of Franco's dictatorship (1939-1975), women's identity was strongly linked to the role of the mother in a very conventional way and this vision has persisted for several decades (Arkinstall, 2002). By the 1990s, Sau (1995) underlined the emptiness of an idea of motherhood reduced to its biological aspects, since this denies its human, economic, social, and political dimensions. In the last 20 years, heterodox motherhoods started emerging both in Spanish society (Martínez et al., 2011) and its children's literature (Lombardo, 2011). Nonetheless, persistent gender inequalities (Canzio, 2021) still reflect a heteronormative vision of family in picturebooks (Vintró, 2008).

Taking this into account, this research intends to provide an overview of the evolution of the role of the mother in Children's Youth Literature (CYL) in Spain, highlighting three main aspects of her character's representation in picturebooks: her feelings and affects, her voice, and her relationship with the rest of the nuclear family.

\section{Context}

Thanks to new social regulations that promote work-life balance and reduce social and economic pressures, as well as the availability of more egalitarian ways of parenting, the degree of women's satisfaction after becoming mothers has apparently increased (Preisner et al., 2020). Still, mothers often feel overburdened and penalized by the demands of combining work and family (Molina \& Montuenga, 2009), making them experience ambivalent emotions caused by gender archetypes and expectations (Almond, 2011). The need to overcome this ambivalence could be considered as the origin of the modern archetype of 'wonder woman', an ideal from 
the 1930s that represents female perfection, coping both with her job and her role at home as a caregiver. The social pressure generated by this archetype still lingers in the twenty-first century (Antoshchuk \& Gewinner, 2020; Gill, 2016; Skorinko et al., 2020). Similarly, the paradigm of the self-sacrificing woman still features (Kaplan, 2013), even if it has updated towards a sort of motherhood mysticism in Spain and America (Hall, 2004) which can be very harmful in terms of physical and psychological wellbeing (Cantillon \& Hutton, 2020).

In adult literature, it has been argued that motherhood itself was not given a leading role until the end of the twentieth century (Hansen, 1997; Podnieks \& O'Reilly, 2010). However, mothers are frequently represented in CYL (Balça et al., 2020), and their representations involve major implications for early learners, as picturesbooks are normally their first contact with the literary world (Botelho \& Rudman, 2009).

The way mothers have recurrently been represented in CYL can be categorised into collective archetypes and imply the assumption of a series of gender stereotypes (Dickman \& Murnen, 2004; Gooden \& Gooden, 2001; Hamilton et al., 2006). Consequently, until very recently (Coats, 2018; Moya-Guijarro \& Cañamares-Torrijos, 2020), the classical paradigm of motherhood differentiated good mothers' (sweet, good, patient, and devoted to the point of sacrifice) from stepmothers (envious, mean, and cruel, see Birkhäuser-Oeri, 2016; Rowe, 1979).

Furthermore, when analysing mothers' representation in CYL, it is interesting to note that the described Manichaean representation always appears from the children's perspective (Gooden \& Gooden, 2001; Hamilton et al., 2006). The voice of the mother is rarely in the centre, and even in those cases in which occasional divergences appeared, they were given a space to highlight them as reprehensible or in need of hiding. Examples of this can be found in Spanish bestselling picturebooks like Madrechillona (Bauer, 2000), where a penguin mother tears her baby to pieces with a cry of rage, and Secreto de familia (Isol, 2003), where maternal imperfection is hidden behind closed doors. In these cases, the represented mother needs to restore her emotional balance after a crisis to return to the archetype of the godmother, as exemplified in other well-known picturebooks in Spain such as Mi madre es rara (Gilmore, 1991).

However, as society changes, so does the role of the mother, in real life and in CYL. With the feminist third wave and even more during the last decade, visions of the mother have been changing, thanks to spaces as heterogeneous as reality shows (Edwards, 2010), TV shows (Wallworth, 2018), or social networks (Hunt, 2009; Rottenberg, 2017). In the case of Spain, this new motherhood is voiced by associations, such as El Club de las Malasmadres (Baena, 2015) or the Asociación Petra Maternidades Feministas, among others, which from a personal revindication became political as they put pressure on the Spanish Government to implement conciliation policies (García, 2020). Even if these associations fight against the traditional vision of the mother in the Spanish imaginary, in Spanish popular television culture there still is a clear trend to associate women to a domestic context or to less ambitious professions, mostly motivated by a major presence linked to emotions or motherhood (Martínez-Rodrigo \& Martínez-Cabeza, 2020). Whereas in the conception of women represented in fiction there have been some advances in the last years (Hidalgo-Marí, 2017), this is not the case in advertising, as the stereotypical framing 
of womens' bodies is increasingly polarised, depending on whether or not they are mothers (Vega et al., 2019).

Within CYL, picturebooks represent an important source for children, both for their format and for their context. Firstly, their visual literacy potential (Horting, 1983) reinforces their literary value but at the same time turns them into aesthetic, artistic, educational and social products (Senís Fernández, 2014). Moreover, from a structural point of view, viewing texts and images together greatly impacts children's conceptualisation literacy process (Arizpe, Farrar, \& McAdam, 2017). Specifically, in Spain, picturebooks are one of the best-selling genres, as their high-quality interests adult readers and has even turned them into collector's items (Ministerio de Educación, Cultura y Deporte, 2017). In addition, recently, they have been granted a great deal of importance in terms of early development, playing an active role in early socialisation, including gender socialisation (Oltra-Albiach \& Pardo-Coy, 2015; Cañamares-Torrijos, \& Moya-Guijarro, 2019; Moya-Guijarro \& CañamaresTorrijos, 2020).

Studies over the past two decades have provided important information on gender representation in CYL, but they generally analyse the main character, often a child (Evans \& Davies, 2000; Gooden \& Gooden, 2001; Hamilton et al., 2006). However, some researchers have studied different representations of parenting (Martin, 2005; Sunderland, 2006; Adams et al., 2011; Moya-Guijarro \& Ventola, 2021). Considering the significance of picturebooks for early learners, surprisingly little attention has been paid to the role of mothers and their gender-stereotyping (Strouse et al., 2018; Moya-Guijarro \& Ventola, 2021).

\section{Methodology}

A systemic functional-multimodal discourse analysis (O'Halloran, 2008) of a selection of picturebooks was performed (Moya-Guijarro, 2014; Painter, 2017), analysing verbal and graphic texts to deduce the deep meaning and content of the picturebooks. Three different perspectives have been applied-semantic, narratological, and sociological - in order to observe the three metafunctions specified by Halliday \& Matthiessen (2014): representational, textual and interpersonal. Three parameters are analysed: the attitude of the character of the mother in the picturebooks (Martín $\&$ White, 2005), the type of narrator that develops the plot so that the main voices can be identified (Kovač, 2017), and the representations of other characters appearing in the picturebook with focus on their relationship with the mother (Frank, 2010).

\section{Sample Selection Process}

The sample was selected by a non-probabilistic convenience process based on the authors' previous knowledge of the editorial context of the picturebook in Spain.

The following parameters were applied to identify the most popular picturebooks on mother characters in Spain during the last 7 years: (1) mothers should appear 
as main characters; (2) they were published by commercially successful publishing houses (Ministerio de Educación, Cultura y Deporte, 2017) -see outlines in Table 1; (3) they were reviewed in prestigious blogs on CYL and childcare with more than 3000 visits a month (monthly traffic calculated using Site Worth Traffic and SemRush, as well-known competitive research engines) (Table 2).

\section{Data Analysis Procedure}

All picturebooks included in the final sample were analysed following a systematic categorisation based on three different parameters: the mother's affects, the type of narrator, and the relationship of the mother with other characters in the picturebooks.

The first parameter dealt with mothers' attitudes: these were codified using the affective subcategorisation established by Martin \& White (2005) applied from a gender perspective as Tian did in 2010 (see Table 3). Even if these models originated in Halliday \& Matthiessen's (2014) systemic-functional linguistics and the semantic areas of emotions (affect), ethics (judgement), and aesthetics (appreciation), in the case of the mothers' affective networks, the first was considered the essential semantic core, as it dealt with the expression of positive and negative feelings (Oteíza, 2017). It must be noted that to explore the changes experienced in the role of the mother in CYL in Spain and how it affects the relationships with the rest of the members of the family, Martín \& White's (2005) categorisation of emotions and their variables was applied. In this categorisation, the concept of affect is paramount in drawn representations of women as it acts as a differentiating element in male and female stereotypes (Leaper \& Friedman, 2007). For the purposes of this study, the mothers' features, both in the picture and the text presenting positive or negative affect emotions, was examined.

The second analysed parameter concerns narratology (Kovač, 2017) and the textual metafunction: it examined the type of narrator, based on the categories established by Genette (1983), i.e., homodiegetic, heterodiegetic, intradiegetic, extradiegetic, and autodiegetic, and explored the repercussions of the narrating voice and its associations with family relationships.

The third parameter, which focuses on Halliday \& Matthiessen's interpersonal metafunction (2014), dealt with the presence of other characters, and aimed to analyse their relationship with the mother from a socio-narratological point of view (Frank, 2010; Santamaría-García, 2021).

\section{Results and Discussion}

This section, departing from the results of the analysis performed, examines the development of the representation of the role of the mother and her relationship with the rest of the members of the nuclear family in the analysed sample. Three main elements will be discussed: the representations of the mothers' affections according to systemic functional linguistics and linking with the visual and literary element, the type of narrator and her relationship with the rest of the members of the family. 


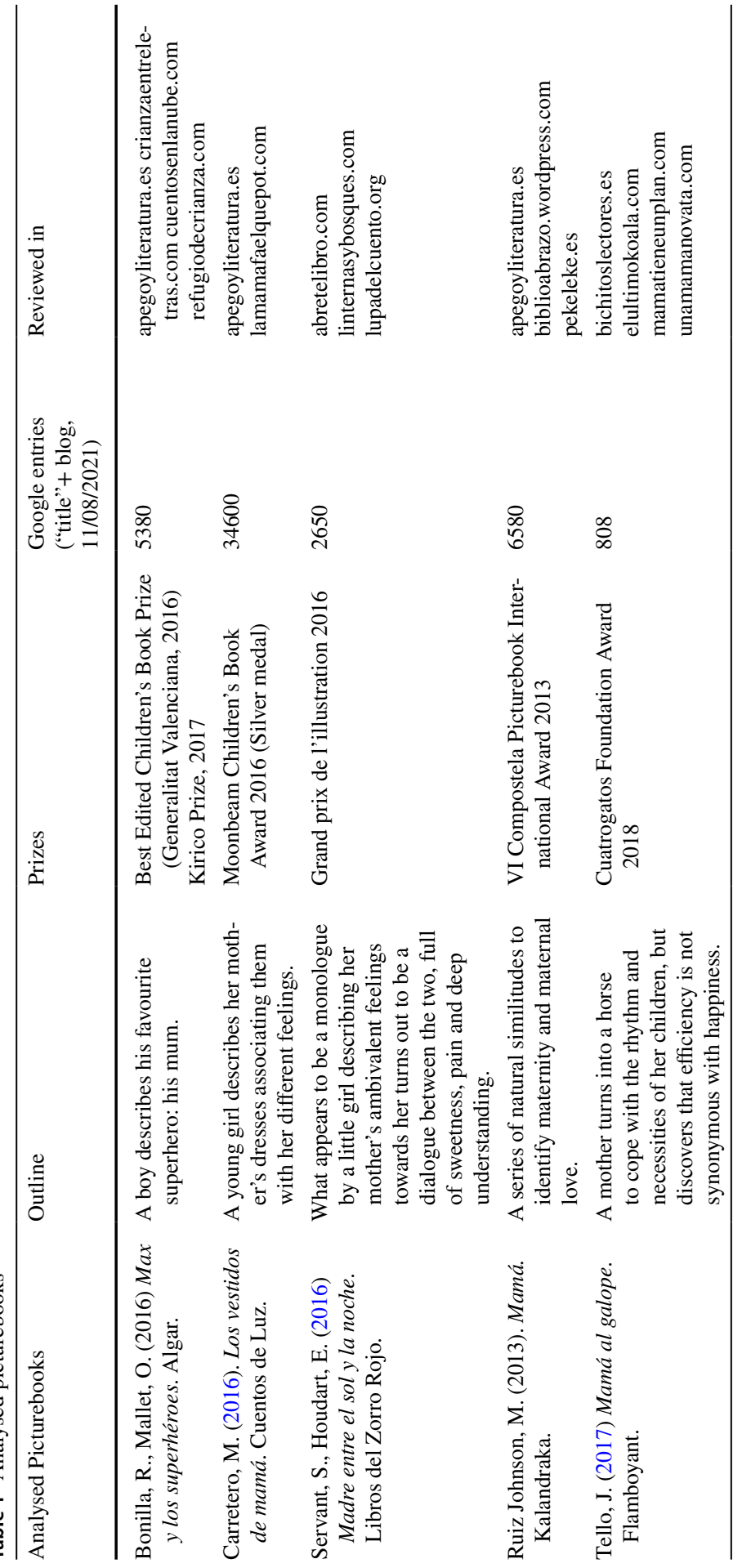




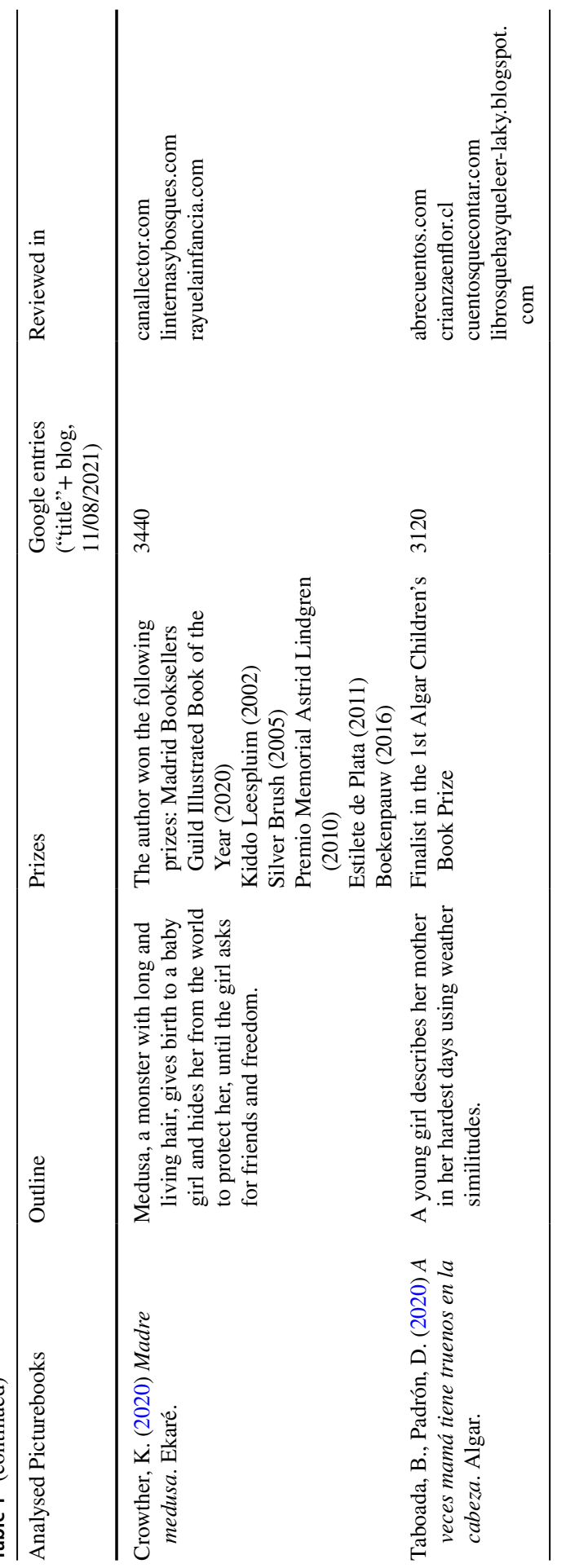


Table 2 Blogs and monthly unique visitors

\begin{tabular}{|c|c|c|}
\hline $\mathrm{B} \log$ & Classification & $\begin{array}{l}\text { Aprox. Monthly Unique Visitors } \\
\text { (source: Site Worth Traffic/Sem- } \\
\text { Rush) }\end{array}$ \\
\hline http://abrecuentos.com/ & CYL & $10860($ SWT $)$ \\
\hline http://abretelibro.com/ & CYL & $23790($ SWT $)$ \\
\hline http://apegoyliteratura.es/ & Childrearing & $20610($ SWT) \\
\hline http://biblioabrazo.wordpress.com/ & CYL & $4100(\mathrm{SR})$ \\
\hline http://bichitoslectores.es/ & CYL & 2880 (SWT) \\
\hline http://canallector.com/ & CYL & $9810($ SWT) \\
\hline http://crianzaenflor.cl/ & Childrearing & 9810 (SWT) \\
\hline http://crianzaentreletras.com/ & Childrearing & 8700 (SWT) \\
\hline http://cuentosenlanube.com/ & CYL & $11900($ SWT $)$ \\
\hline http://cuentosquecontar.com/ & CYL & $10380($ SWT $)$ \\
\hline http://elultimokoala.com/ & Childrearing & $62000(\mathrm{SR})$ \\
\hline http://lamamafaelquepot.com/ & Childrearing & $3400(\mathrm{SR})$ \\
\hline http://librosquehayqueleer-laky.blogspot.com/ & CYL & $13900(\mathrm{SR})$ \\
\hline http://linternasybosques.com/ & CYL & $16290($ SWT) \\
\hline http://lupadelcuento.org/ & CYL & 7170 (SWT) \\
\hline http://mamatieneunplan.com/ & Childrearing & $18600(\mathrm{SR})$ \\
\hline http://pekeleke.es/ & Childrearing & $12870(\mathrm{SWT})$ \\
\hline http://rayuelainfancia.com/ & CYL & $20500(\mathrm{SR})$ \\
\hline http://refugiodecrianza.com/ & Childrearing & $17250(\mathrm{SWT})$ \\
\hline http://revistababar.com/ & CYL & 9810 (SWT) \\
\hline http://unamamanovata.com/ & Childrearing & $27500(\mathrm{SR})$ \\
\hline
\end{tabular}

In this regard, the analysis of the lack of presence of the father figure and the relationships between the mother and her children -with special attention to the relationship with daughters- is emphasised.

\section{Representation of the Mother's Affects}

All images and texts reveal very specific affects and feelings coming from the analysed representations of the mother, towards both themselves and other family members.

In Table 3, even if the extremes were balanced, there appears a significant trend towards reflecting positive aspects, which means that "good" feelings about motherhood were always present. However, it is interesting to note that, in some cases, there are complete absences of negative aspects, e.g., in Max y los superhéroes (Bonilla \& Mallet, 2018), or partial ones as in Los vestidos de mamá (Carretero, 2016), with just one reference to sadness. The rest of the picturebooks covered a great variety of affects that include sadness, unhappiness, stress, anxiety, fear, discomfort, aversion and even boredom. Despite a certain degree of 


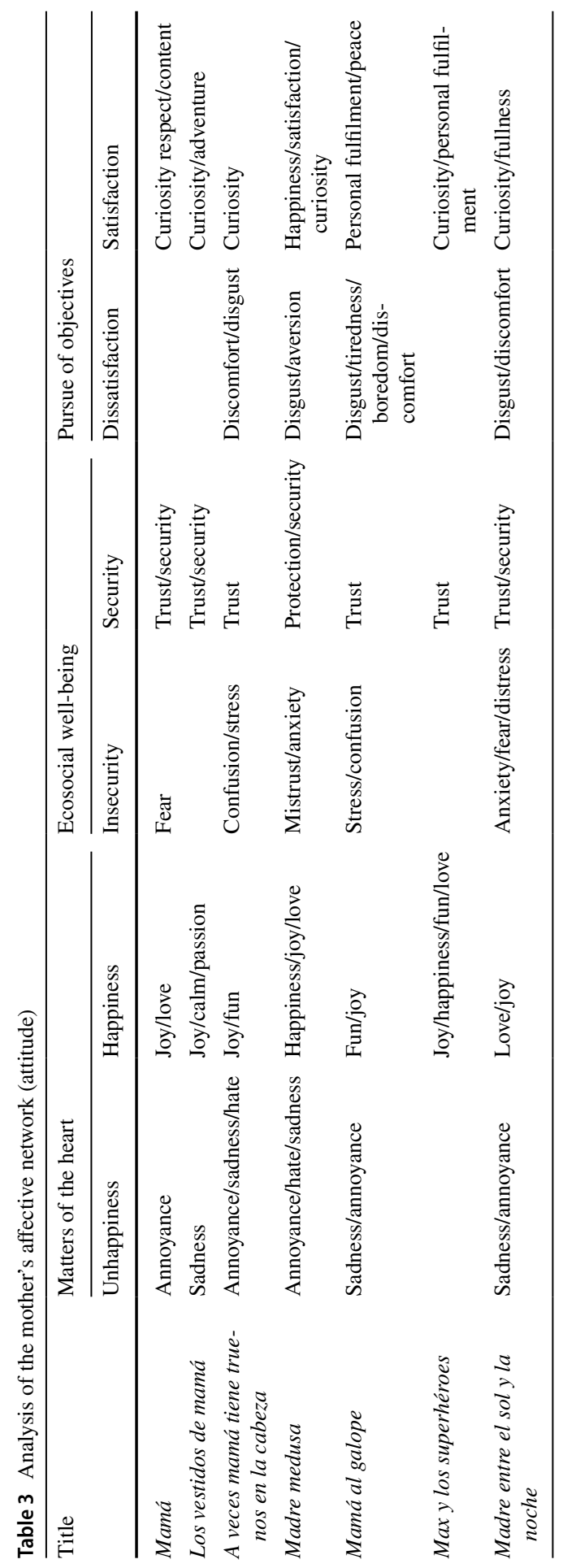


acknowledgement of fear linked to ecosocial wellbeing, the lack of affects associated with the mothers' dissatisfaction in the pursuit of objectives is remarkable.

From the dichotomous perspective mentioned in the context, the analysed picturebooks start to overcome the archetype of the good mother (see Table 3) as the mother in fact has a voice and the right to explore her own negative and positive feelings. The sample shows a balance in most of the picturebooks between positive and negative polarities. However, as explained further, there still appears to be some resistance to dealing with negative feelings.

One of the analysed picturebooks can be traced back to the tradition of the perfect mother from liberal feminism: Max y los superhéroes (Bonilla \& Mallet, 2018). Even if she is represented as a wonder woman with no room for imperfections (see Fig. 1), the protagonist of this story does not seem to be uncomfortable, as she is depicted, in a comic-like fashion, as a superheroine who can solve any working or domestic problem. There is a sort of masculinisation of women; Sau (2001) arguing that the metaphor of the superheroine is not an innocent one, as even when introduced into public and work spheres, does not neglect the care duties attributed to hyper-feminised women.

In this regard, Mamá al galope (Tello, 2017) deals with that overload from a different approach: the main character must become a horse to meet all the demands of being a mother. The picturebook uses humour for an estrangement effect, as the mother is thankful for the transformation, until she realises that she has lost her real identity (see Fig. 2). The mother has completely lost her own voice in the pursuit of a frustrating, standardised role (see Table 3 for the lack of positive polarity in the pursuit of aims in Mamá al galope).

The picturebook Mamá (Ruiz Johnson, 2013) shows a completely contrary perspective. The main character is defined by her own son as 'a universe that everything hides' (Ruiz Johnson, 2013, pp. 22-23), inaugurating a close-to-nature form of mothering (Martucci, 2015; Mellor, 2018). The mother in this work feels fears and sadness, even though negative emotions connected with ecosocial wellbeing or the pursuit of aims (see Table 3) were systematically sweetened. This picturebook is associated with a kind of feminism that reclaims female qualities such as sensibility, intuition, less aggression, and the capacity to protect and

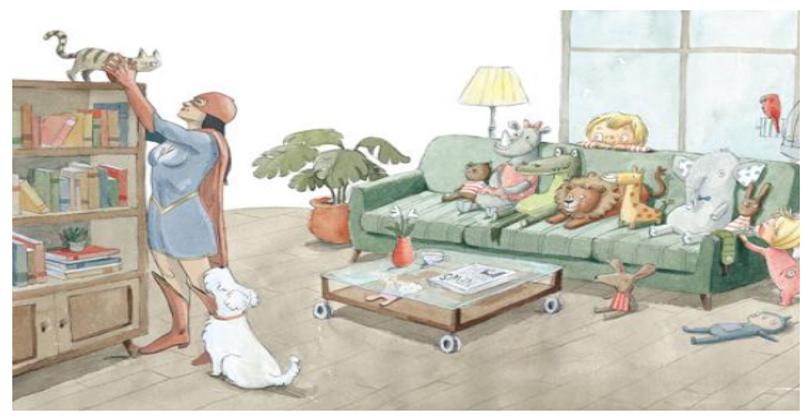

Fig. 1 The supermother saving all the pets of the house (Bonilla \& Mallet, 2018, pp. 31-32). Courtesy of the publisher. @2018. Algar. Max y los superheroes. Text and illustrations Rocío Bonilla \& Oriol Mallet 
Fig. 2 The mother, transformed into a horse, crying while holding her daughter's hand (Tello, 2017, p. 31). Courtesy of the publisher. (C) 2017, Editorial Flamboyant. Mamá al galope. Text and illustrations by Jimena Tello

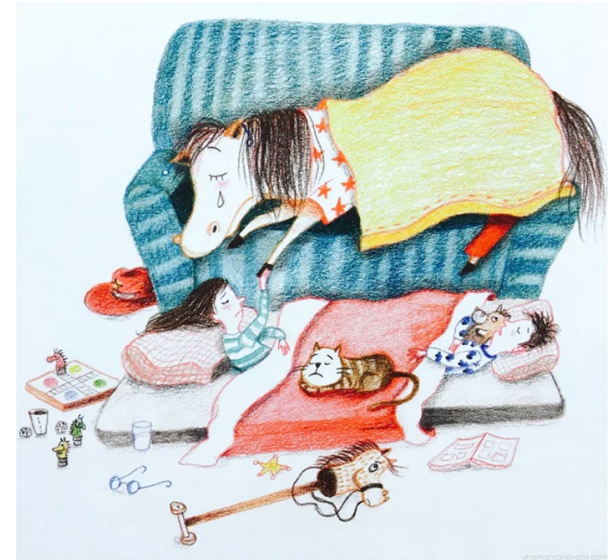

care (Stephens, 2012), assuming that these are the universal characteristics of all women (see Fig. 3).

Something different happens in Los vestidos de mama (Carretero, 2016), where the mother changes her dress on every page, showing the different emotions or activities that a person can experience in a day. However, the picturebook lacks emotional complexity, as only superficial sadness is addressed, without hint of deeper investigation (Fig. 4).

On the contrary, in A veces mamá tiene truenos en la cabeza (Taboada \& Padrón, 2020), there is a crescendo in the expression of negativity, which is balanced by the positive affections. The main character is saddened, angered and bored by society's demands or lack of aims (see Fig. 5). Nevertheless, the

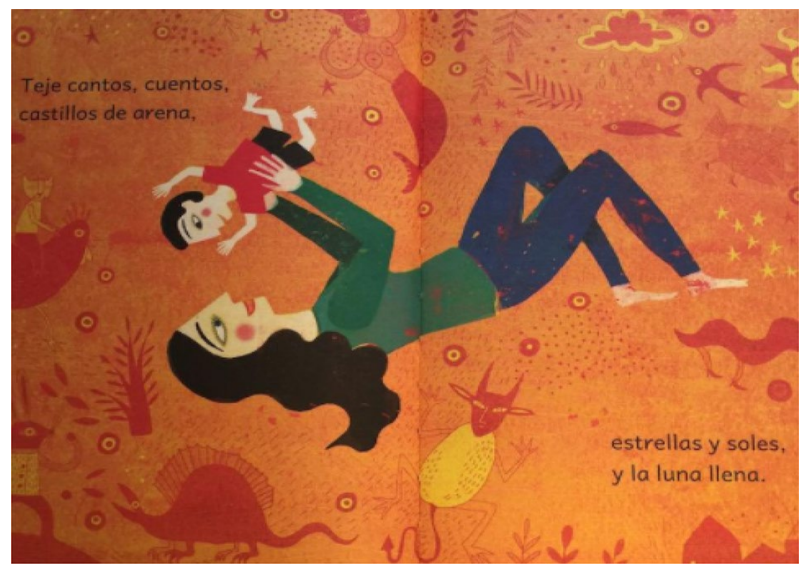

Fig. 3 The mother peacefully plays with her son, surrounded by sea elements (Ruiz Johnson, 2013, pp. 16-17). Courtesy of the publisher. @ 2013, Editorial Kalandra. Mamá. Text and illustrations by Mariana Ruiz Johnson 


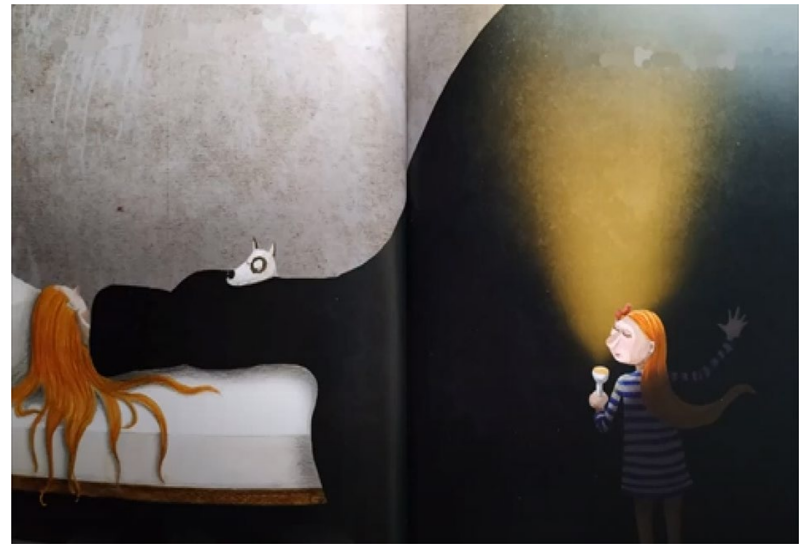

Fig. 4 The daughter, holding a torch, observes her mother lying in bed dressed in black (Carretero, 2016, pp. 14-15). Courtesy of the publisher. @ 2016, Cuentos de luz. Los vestidos de mamá. Text and illustrations by Mónica Carretero

expression 'a veces' (sometimes) in the title states that the mother is not always bad-tempered.

Regarding affective complexity, the picturebook with more subtleties in the emotional tone is Madre entre el sol y la noche (Servant \& Houdart, 2016). This work opens doors to a variety of affections of negative and positive polarisations (see Table 3). Associated with the natural current of mothering, it does not avoid traditionally silenced topics such as the puerperium (Zivoder et al., 2019). However, in Madre entre el sol y la noche (Servant \& Houdart, 2016), the protagonist's own identity is more precisely underlined, with no need for it to be universal.

Madre Medusa (Crowther, 2020) can also be included in this demythologizing current. This picturebook presents a monstrous, enigmatic creature whose long hairs move about and perform all manner of maternal functions (see Fig. 6). It is a metaphoric narration about motherly love and the protective instinct that touches all

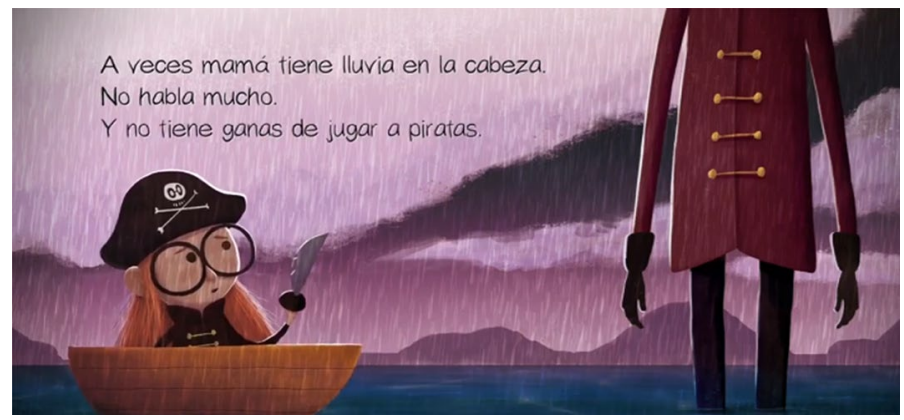

Fig. 5 In the middle of a tempest, the daughter, dressed as a pirate, observes her mother -seen in section thus genderless- from her boat (Taboada \& Padrón, 2020, pp. 7-8). Courtesy of the publisher. @ 2020, Algar. A veces mamá tiene truenos en la cabeza. Text by Bea Taboada and illustrations by Dani Padrón 


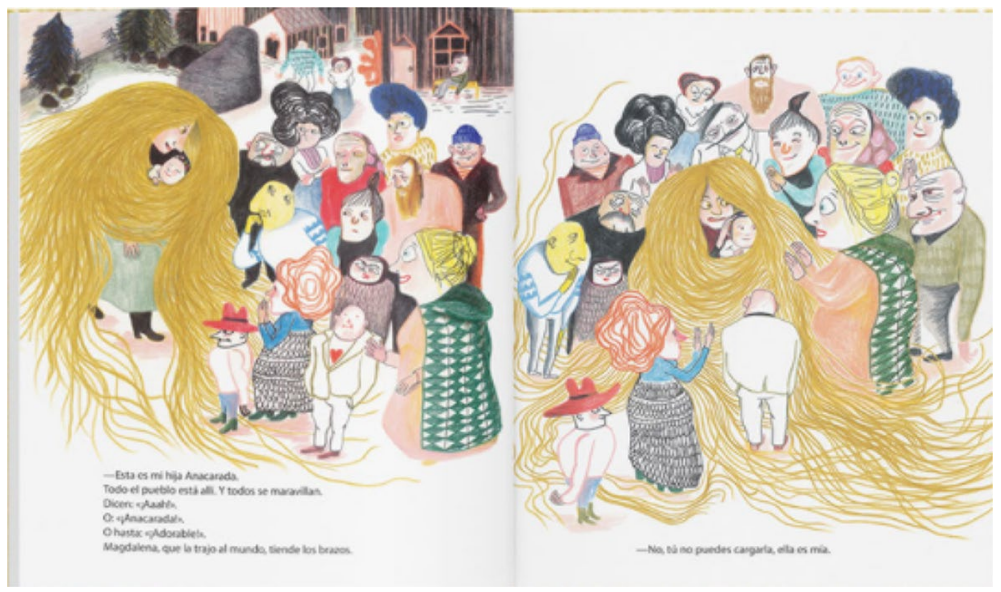

Fig. 6 Madre Medusa introduces her daughter to the people, but does not let anyone hold her (Crowther, 2020, pp. 14-15). Courtesy of the publisher. @ 2014, l'école des loisirs. Mére Méduse. Text and illustrations by Kitty Crowther. Rights acquired through Isabelle Torrubia Literary Agency. 2016, translation: María Carolina Concha. @ 2020, of this edition. Madre Medusa. Text and illustrations by Kitty Crowther. Ediciones ekaré

kinds of affections (see Table 3), positively and negatively, rejecting the heteronormative dimension of motherhood throughout.

\section{Type of Narrator}

Following the classification established by Genette (1983), the analysis of the narrating voices in these picturebooks reveals that, in most cases, the story is told by a daughter of the protagonist. It is no surprise: daughters are the characters who discover the identities and contradictions of their own mothers (see Tables 4, 5). When the narrator is extradiegetic, the co-protagonists might be a son (Max y los superhéroes) or a daughter (Madre Medusa).

Looking at all the characters in the narration, there was no other carer apart from the mother. No father figure was included in the picturebooks, except for Madre

Table 4 Narrating voices

\begin{tabular}{lll}
\hline Extradiegetic narrator & Intradiegetic narrator (son) & Intradiegetic narrator (daughter) \\
\hline & $\begin{array}{l}\text { Mamá } \\
\text { Mamá al galope }\end{array}$ & Madre entre el sol y la noche \\
&
\end{tabular}

Madre Medusa

Los vestidos de mamá

Max y los superhéroes

A veces mamá tiene truenos en la cabeza 
Table 5 Other characters

\begin{tabular}{ll}
\hline Picturebook & Other characters \\
\hline Mamá & Son \\
Los vestidos de mama & Daughter \\
A veces mamá tiene truenos en la cabeza & Daughter \\
Madre medusa & Daughter, midwives \\
Mamá al galope & Son, daughter \\
Max y los superhéroes & Son \\
Madre entre el sol y la noche & Daughter, father \\
\hline
\end{tabular}

entre el sol y la noche (Servant \& Houdart, 2016). In Madre Medusa (Crowther, 2020), a group of midwives appear, but even if they do help the main character to give birth, Madre Medusa throws them out once her daughter has been born. Children appear in all the analysed picturebooks, with a higher presence of females $(71 \%$ include daughters, $43 \%$ include sons).

\section{Other Family Members and Their Relationship with the Mother}

As Halliday \& Matthiessen (2014) underline, interpersonal metafunction puts the accent on the relationships we create around us as a way to convey meaning. Therefore, to understand the role of the mother in picturebooks, it is necessary to observe the relationships that this character creates with her environment.

\section{Absent Fathers?}

The nearly complete absence of the paternal figure in the picturebooks does not come as a surprise. Anderson \& Hamilton's (2005) analysis of the differences between the roles of mothers and fathers showed an unequal representation of parents, with stereotyped father representations "significantly underrepresented, and presented as unaffectionate" (p. 149). Even if a slight progression towards the role of a more involved father has been observed (Adams et al., 2011), filiation is still a universal construct (Ross, 2017), which devolves almost exclusively to the mother's responsibility.

The scarce presence of the figure of the father in the analysed picturebooks cannot be interpreted in any other way. The absence of the father in the analysed picturebooks is, therefore, intended to place the figure of the mother at the forefront, providing her with an absolute voice. And here, the mother may be performing the role of super carer, to which she is traditionally relegated-as in Max y los superheroes (Bonilla \& Mallet, 2018), or of which she is bored-as in Mamá al galope (Tello, 2017). This implies that motherhood is far from being valued by society, as revealed by the complexity of negative affections in the part devoted to ecosocial wellbeing (see Table 3). In Spanish literature, women's representations have traditionally been established under patriarchal values and, therefore, motherhood as a non-patriarchal institution does not exist as its representations lack any cultural, 
ethical, or social functions if mothers have always been considered as mere carriers of future subjects (Showalter, 1978).

In this sense, further examination of Madre entre el sol y la noche (Servant \& Houdart, 2016) is necessary, as it is the only picturebook included in the sample in which the figure of the father explicitly appears. It is a brief appearance that is not linked to the daughter's upbringing. In fact, as seen in Fig. 7, the father appears as taking care of his partner, not his daughter. This perspective shows the couple's attention to the social role of the mother, and, consequently, depatriarchalizes the man from the role of mere provider or house-chore helper, and places him in the context of a carer.

This is a clear example of female literature (Showalter, 1978), as also seen in the use of poetic and metaphoric language: text and pictures are finally focused on an authentic analysis of the feelings associated with motherhood. The mother is the centre of the picturebook, but as a complete woman, experiencing that particular stage of her life.

\section{Mothers and Sons... and Daughters}

Logically, as the concept of maternity implies creating unbreakable ties between the mother and child, children appeared in all the analysed picturebooks. The study of the ties established in these texts implies, for that very reason, understanding the notion of motherhood that each of the picturebooks tries to convey.

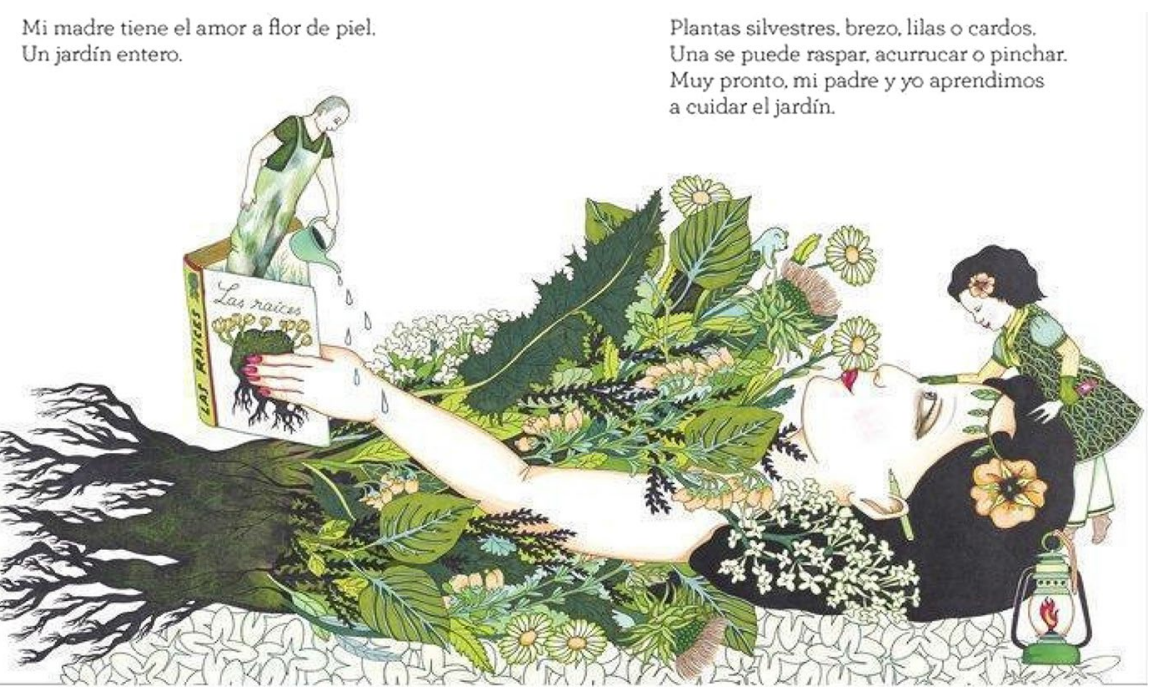

Fig. 7 The mother embodying a plant is lying while the father waters her and the daughter observes and caresses her (Servant \& Houdart, 2016, pp. 8-9). Original title: Ma mere. (C) 2015, Éditions Thierry Magnier. Text by Stéphane Servant and illustrations by Emmanuelle Houdart. Rights acquired through Isabelle Torrubia Literary Agency. 2016, translation: Luisa Antolín Villota. (C) 2016, of this edition: Libros del Zorro Rojo 
Showalter's (1978) triad of feminine, feminist and female writing becomes particularly explicit when it comes to the analysis of these ties, specifically when the narrating voices in the picturebooks are examined (see Table 4). In all cases, listening to themselves through their children's voices-or reading themselves through their children's eyes- enables mothers, who are simultaneously characters and readers, to grasp their under-construction identities. It should be noted that in the picturebooks representing feminist literature, in which female characters defend their capacities while expressly or implicitly confronting the patriarchal omnipresence, all the children are male. Examples of this are Max y los súperheroes (Bonilla \& Mallet, 2018), representing the role of wonder woman, and Mamá (Ruiz Johnson, 2013), where the mother embodies universal nature (Puleo, 2002). Moreover, in Max y los súperheroes (Bonilla \& Mallet, 2018) the narrator is extradiegetic (Table 4), and therefore, the mother's voice appears filtered from somebody else's perspective. However, female writing, more mature, and richer in contradictions, only seems to emerge when the co-protagonists are daughters.

However, the emphasis on the tie between mother and daughter is more than an ideological trend. This tie obviously differs from the mother-and-son bond, as the former includes the emotional legacy of the maternal model (Marsh, 2012). As early as 1976, Rich warned of the fact that 'the cathexis between mother and daughteressential, distorted, misused- is the great unwritten story' (p. 227). Burin (2017), when examining construction of subjectivities, pointed out that the mother would experience a stronger feeling of uniqueness and continuity with her daughter than with her son. It is evident that there still is an unconscious ideal of motherhood that is transmitted by the archetype represented by girls in their games (Alizade, 2006). Nonetheless, some of these picturebooks convey the need for the daughter to break free from that, and it is peculiar that girls, and not boys, are the co-protagonists and the narrators of the story. In Los vestidos de mamá (Carretero, 2016), the daughter identifies and recognises the mother's different moods, even if there is a lack of visual contact between mother and daughter, as if disconnecting was necessary to be able to emotionally detach from the progeny.

This does not happen in A veces mi mama tiene truenos en la cabeza (Taboada \& Padrón, 2020): negative emotions are welcomed, without any taint of guilt, and the contact between mother and daughter allows this growth and self-acceptance, even if it happens in a vertical sense, with the mother being responsible for the daughter's learning (see Fig. 5). In Madre Medusa (Crowther, 2020), perhaps one of the most ground-breaking picturebooks analysed, the verticality of this learning is broken. At the beginning of the picturebook, the contact between mother and daughter is oppressive. The daughter is identified by the mother as an extension of herself who must be jealously guarded. It is the daughter herself who finally asks for space, with an empathic dialogue that offers a relationship as equals: the daughter's education finally escapes from the verticality of twentieth century patriarchal structures. In this regard, it is interesting that the narration is directed by an extradiegetic narrator (see Table 4), who observes the whims of mother and daughter without judging.

Therefore, the evolution of the mother-daughter relationship has been examined by exemplifying it, moving from a clear separation and a vertical relationship to a horizontal and osmotic growth. The pinnacle of all these relationships 
appears in Madre entre el sol y la noche (Servant \& Houdart, 2016), where the specular connection between mother and daughter is represented. The story is narrated through the voice of the daughter, who is represented exactly as her mother but on a smaller scale. Most of the symbols they carry were passed to one another through the narration: the balls of yarn, the oil lamp, the doll, the rake, but also a bird's body and tears. As happens in A veces mama tiene truenos en la cabeza (Taboada \& Padrón, 2020), not only does the anger felt by one character justify the anger of the other, but they also forge an alliance of care, a network of support, a secure base for true mutual development. While the mother was crying, the daughter knitted a glove: by knitting, she repeated and perpetuated maternal actions (in the first image the mother was carrying skeins), but also showed she cared (the knitting as a sign of love and warm protection) and prepared for a potentially complicated cohabitation, as the gloves recall falconry (and in the symbiosis of the falcon and the falconer, the glove is the safe perch for the falcon, and at the same time protects the falconer from the bird's talons).

However, the mother immediately made it clear to her daughter that their tie was not threatened even if she was absent, showing a secure attachment that separates her from the model of the unconditional mother (Turin, 1995). The mother supported her own inner child (Miller, 1981) and the daughter accepted that her mother's heart was 'between the sun and the night', while she held an oil lamp of her own.

It has been argued that social constructs regarding what is male or female are not physiological, but cultural, as they emerge from a performative and imitative practice (Butler, 1990). Therefore, if children and mothers themselves, as readers of the picturebooks, continue to perpetuate an idealised image of sacrificed and darkness-free motherhood (Kaplan, 2013), that archetype will probably never be modified. Non-mystified writing on and about the mother, then, implies a liberation for daughters, an overcoming of matrophobia (Rich, 1976). However, this also implies, for sons and daughters alike, a display of emotions that are not traditionally associated with their assigned gender roles (Bronstein et al., 1996), with the resulting capacity for generating a new vision of the male and the female. Indeed, one fact that reveals the overcoming of gender in the univocal identification of the daughter with the figure of the mother is that the author of the text of Madre entre el sol y la noche is a man, Stéphane Servant (an exception among all the picturebooks). If we forget the label of men/women and, by extension, father/ mother with all the associated social constructs, and if we work on the public and personal spheres to transform the family into a mutual support network, the whole family structure will be reinforced. Generally, a respected motherhood that accepts all different kinds of affections can facilitate a more complete psychosocial development for all the family (Boyum \& Parke, 1995; Cassidy et al., 1992). At the same time, it should be noted that the relationships of these characters is no longer unidirectional, but multidimensional, considering other aspects outside the family. To sum up, leaving behind the binary simplification that supports the patriarchal system (Sendón, 2002) and which limits mothers and fathers to their traditional roles. 


\section{Implications}

Even if there is a current trend towards fostering the use of neutral terms for parenting in the implementation of current policies, the experiences of mothers and fathers of family life are still strongly influenced by gender (Veazey, 2018). Moreover, there is a clear disconnection between the biological reality of a woman and what society expects from her: this leads to a series of clichés that contribute to an excessive and stereotypical burden placed on the figure of the mother (Chrisler, 2013) which this study has found reflected in CYL. Fortunately, women have found their own social and artistic paths to rise against this generalised attitude, both in the field of literature and in society itself. Based on these changes, the analysed picturebooks clearly unmask the existing conflicts that arise when contrasting the reality of motherhood with the ideal. Some of these picturebooks manage to eradicate the romantic images of parenthood, as portrayed by popular and social media which, along with ideologies and expert counselling, have contributed to increased family stress (Harries \& Brown, 2017).

Also, in Madre entre el sol y la noche and Madre Medusa, the analysed picturebooks openly criticise capitalist society and its attempt 'to privatise childrearing and, at least discursively, to cast parenthood as a private choice rather than one that merits state support' (Johnston-Ataata, 2018, p. 193).

The relevance of these narrations regarding the children is also interesting, as, generally, they do not show the inevitability of passive suffering (Rich, 1976) in the sense of sacrifice, but a revelation of suffering as a normal transformation process, that is progressively revealed as an empowering element (O'Reilly, 2012).

Taking mothers away from the role of victims and essential carer also leaves space for new forms of masculinity and fatherhood that are not focused on the role as breadwinner or as mere helper with the housework. The implications for literature are that, not only could we delve into a redefinition of what it means to be a woman and a mother, but we could also support a redefinition of the family sphere and the networks and social links surrounding it.

\section{Conclusions}

Despite its exploratory nature, this study offers some insights into the characterisation of mothers in picturebooks read in Spain over the last 5 years. Although the sample is relatively limited, the parameters applied for the selections of the picturebooks guaranteed a selection that offers valuable insights into the aspects that are currently transforming the mother's representation in CYL.

Notwithstanding these limitations, the present study extends the literature on the representation of mothering in picturebooks, focusing on the current publishing scene in Spain. The repertoire of books analysed in this article, which brings together the most widely read, awarded and sold texts in Spain over the last 7 years with the mother as a central character, seems to show that the country has 
finally begun to leave behind a traditional, conservative imagery associated with motherhood, which used to limit being a mother to a universal experience of selfdenial when positive, versus cruel rejection when negative.

The analysed picturebooks allow us to distinguish the emergence of a more complex characterisation of mothers, their affections and their relationships with the rest of the family members. Even if some of the studied texts still refer to a 'close to nature' form of mothering (Ruiz Johnson, 2013) or to 'super mothers' (Bonilla \& Mallet, 2018), both still mirroring a predominantly patriarchal vision of motherhood, other texts finally challenge this perfectionist and mercantilist reading of reality (Tello, 2017). Picturebooks such as A veces mamá tiene truenos en la cabeza (Taboada \& Padrón, 2020) or Los vestidos de mamá (Carretero, 2016) give a genuine voice to mothers and allow them to shape - together with their children, specifically their daughters - an identity in constant transformation and redefinition. At last, the ambivalence of maternal feelings, which are not always positive, not always serene, almost never universal, is acknowledged: the mother is finally legitimised as an all-round adult subject, in whom moments of extroversion and introversion, and even angry aspects can perfectly coexist. Furthermore, there is no longer need to hide this complexity, or to apologise for it: the mother, as the protagonist of these texts and often the mediator of their reading to children, investigates her own identity in a space shared with the young readers, that of the picturebook itself. The family, inside and outside the page, is resemantized: roles are exchanged, growth becomes collective and synchronic; love, like empathy, is learned by loving and being loved, in a virtuous circle of affection and care that is, first of all, self-caring.

Author contributions (optional: please review the submission guidelines from the journal whether statements are mandatory). Not applicable.

Funding Open Access funding provided thanks to the CRUE-CSIC agreement with Springer Nature. This work was supported by TRANS.ARCH Project. Archives in Transition: Collective Memories and Subaltern Uses, from Horizon 2020 programme, ID: 872299 of European Union.

Data Availability of data and material (data transparency) Not applicable.

Code availability (software application or custom code) Not applicable.

\section{Declarations}

Conflict of interest The authors have no conflicts of interest to declare that are relevant to the content of this article.

Ethical Approval (include appropriate approvals or waivers) Not applicable.

Research Involving Humans and/or Animals Not applicable.

Consent to Participate (include appropriate statements) Not applicable.

Consent for Publication (include appropriate statements) Not applicable. 
Open Access This article is licensed under a Creative Commons Attribution 4.0 International License, which permits use, sharing, adaptation, distribution and reproduction in any medium or format, as long as you give appropriate credit to the original author(s) and the source, provide a link to the Creative Commons licence, and indicate if changes were made. The images or other third party material in this article are included in the article's Creative Commons licence, unless indicated otherwise in a credit line to the material. If material is not included in the article's Creative Commons licence and your intended use is not permitted by statutory regulation or exceeds the permitted use, you will need to obtain permission directly from the copyright holder. To view a copy of this licence, visit http://creativecommons.org/licen ses/by/4.0/.

\section{References}

Adams, Mathew, Walker, Carl, and O'Connell, Paul (2011). Invisible or Involved Fathers? A Content Analysis of Representations of Parenting in Young Children's Picturebooks in the UK. Sex Roles, 65(3-4), 259-270. https://doi.org/10.1007/s11199-011-0011-8.

Alizade, Alcira. (2006). Motherhood in the Twenty-First Century. New York: Karnac.

Almond, Barbara. (2011). The Monster Within: The Hidden Side of Motherhood. Berkeley: University of California Press.

Anderson, David, and Hamilton, Mykol (2005). Gender Role Stereotyping of Parents in Children's Picture Books: The Invisible Father. Sex Roles, 52, 145-151. https://doi.org/10.1007/s11199-005-1290-8.

Arizpe, Evelyn, Farrar, Jennifer., \& McAdam, Julie (2017). Picturebooks and Literacy Studies. In B. Kümmerling-Meibauer (Ed.), The Routledge Companion to Picturebooks (pp. 371-380). London: Routledge.

Antoshchuk, Irina A., and Gewinner, Irina (2020). Still a Superwoman? How Female Academics from the Former Soviet Union Negotiate Work-Family Balance Abroad. Monitoring of Public Opinion: Economic and Social Changes, 1, 408-435. https://doi.org/10.14515/monitoring.2020.1.17.

Arkinstall, Christine (2002). Towards a Female Symbolic: Re-Presenting Mothers and Daughters in Contemporary Spanish Narrative by Women. In A. Giorgio (Ed.), Writing Mothers and Daughters: Renegotiating the Mother in Western European Narratives by Women, (pp. 47-84). New York: Berghahn Books.

Baena, Laura. (2015). Soy buena malamadre. El libro del club Malasmadres. Barcelona: Lunwerg.

Balça, Ángela., Selfa Sastre, Moisés, and Azevedo, Fernando (2020). Children's Literature and Emotions: Mother-Child Relationship. Tejuelo. Revista De Didáctica De La Lengua y La Literatura, 32 , 55-82. https://doi.org/10.17398/1988-8430.32.55.

Bauer, Jutta. (2000). Madrechillona. Madrid: Lóguez.

Birkhäuser-Oeri, Silvia. (2016). La llave de oro: Madres y madrastras en los cuentos infantiles. New York: Turner.

Bonilla, Rocío, and Mallet, Oriol. (2018). Max y los superhéroes. Uberlândia: Algar.

Botelho, María José., and Rudman, Masha. (2009). Critical Multicultural Analysis of Children's Literature: Mirrors, Windows, and Doors. London: Routledge.

Boyum, Liss, and Parke, Ross (1995). The Role of Family Emotional Expressiveness in the Development of Children's Social Competence. Journal of Marriage and Family, 57(3), 593-608. https://doi.org/ $10.2307 / 353915$.

Bronstein, Phyllis, Briones, Maria, Brooks, Teri, and Cowan, Brookes (1996). Gender and Family Factors as Predictors of Late Adolescent Emotional Expressiveness and Adjustment: A Longitudinal Study. Sex Roles, 34, 739-765. https://doi.org/10.1007/BF01544314.

Burin, Mabel (2017). A veinte años del foro de psicoanálisis y género: mis aportes a la construcción de un campo complejo. In Irene Meler (Ed.), Psicoanálisis y Género. Escritos sobre el amor, el trabajo, la sexualidad y la violencia (pp. 45-69). Barcelona: Paidós.

Butler, Judith. (1990). Gender Trouble: Feminism and the Subversion of Identity. Thinking Gender. London: Routledge.

Canzio, Leandro I. (2021). Division of Housework Within Couples in Spain: Consequences of Educational Differences and Women's Gender-Egalitarian Beliefs. Papers: Revista De Sociologia, 106(1), 59-94. https://doi.org/10.5565/rev/papers.2750. 
Cantillon, Sara, and Hutton, Martina (2020). Exploring Self-Sacrifice, Role Captivity, and Motherhood. In K. Levasseur, S. Paterson and L.A. Turnbull (Eds.), Mothering and Welfare: Depriving, Surviving, Thriving, (pp. 151-166). Toronto: Demeter Press. https://doi.org/10.2307/j.ctv16pn3d9.12.

Cañamares-Torrijos, C., and Moya-Guijarro, A.J. (2019). Análisis semiótico y multimodal de los escenarios de libros álbumes que retan estereotipos de género. Ocnos: Revista De Estudios Sobre Lectura, $18(3), 59-70$.

Carretero, Mónica. (2016). Los vestidos de mamá. Madrid: Cuentos de luz.

Cassidy, Jude, Parke, Ross D., Butkovsky, Laura, and Braungart, Julia M. (1992). Family-Peer Connections: The Roles of Emotional Expressiveness Within the Family and Children's Understanding of Emotions. Child Development, 63(3), 603-618. https://doi.org/10.1111/j.1467-8624.1992.tb016 49.x.

Chrisler, Joan C. (2013). Teaching Taboo Topics: Menstruation, Menopause, and the Psychology of Women. Psychology of Women Quarterly, 37(1), 128-132. https://doi.org/10.1177/0361684312 471326.

Coats, K. (2018). Gender in Picturebooks. In B. Kümmerling-Meibauer (Ed.), The Routledge Companion to Picturebooks, (pp. 119-127). London: Routledge.

Crowther, Kitty. (2020). Madre medusa. Barcelona: Ediciones Ekaré.

Dewitt, Amy L., Cready, Cinthya M., and Seward, Rudy R. (2013). Parental Role Portrayals in Twentieth Century Children's Picture Books: More Egalitarian or Ongoing Stereotyping? Sex Roles, 69(1-2), 89-106. https://doi.org/10.1007/s11199-013-0285-0.

Diekman, Amanda B., and Murnen, Sarah K. (2004). Learning to be Little Women and Little Men: The Inequitable Gender Equality of Nonsexist Children's Literature. Sex Roles, 50(5-6), 373-385. https://doi.org/10.1023/B:SERS.0000018892.26527.ea.

Edwards, L.H. (2010). Reality TV and the American family. In J. Taddeo \& K. Dvorak (Eds.), The Tube has Spoken: Reality TV \& history (pp. 123-144). Lexington: The University Press of Kentucky.

Evans, L., and Davies, K. (2000). No Sissy Boys Here: A Content Analysis of the Representation of Masculinity in Elementary School Reading Textbooks. Sex Roles, 42(3), 255-270.

Frank, A.W. (2010). Letting Stories Breathe: A Socio-narratology. Chicago: University of Chicago Press.

García, C. (2020). Cuando ser madre te convierte en invisible. El País. Madrid. https://elpais.com/elpais/ 2020/02/12/mamas_papas/1581504941_105353.html.

Genette, Gérard. (1983). Narrative Discourse: An Essay in Method. Ithaca: Cornell University Press.

Gill, Rosalind (2016). Breaking the Silence: The Hidden Injuries of Neo-liberal Academia. Feministische Studien, 34(1), 39-55. https://doi.org/10.1515/fs-2016-0105.

Gilmore, Jones. (1991). Mi madre es rara. Barcelona: Editorial Juventud.

Gooden, Angela, and Gooden, Mark (2001). Gender Representation in Notable Children's Picture Books 1995-1999. Sex Roles, 45(1), 89-101. https://doi.org/10.1023/A:1013064418674.

Hall, Linda B. (2004). Mary, Mother and Warrior: The Virgin in Spain and the Americas. Austin: University of Texas Press.

Halliday, Michael, and Matthiessen, Christian. (2014). An Introduction to Functional Grammar. London: Routledge.

Hamilton, Mykol, Anderson, David, Broaddus, Michelle, and Young, Kate (2006). Gender Stereotyping and Under-Representation of Female Characters in 200 Popular Children's Picture Books: A Twenty-First Century Update. Sex Roles, 55(11-12), 757-765. https://doi.org/10.1007/ s11199-006-9128-6.

Hansen, Elaine T. (1997). Mother Without Child: Contemporary Fiction and the Crisis of Motherhood. Berkeley: University of California Press.

Harries, Victoria, and Brown, Amy (2017). The Association Between Use of Infant Parenting Books That Promote Strict Routines, and Maternal Depression, Self-efficacy, and Parenting Confidence. Early Child Development and Care, 188(8), 1339-1350. https://doi.org/10.1080/03004430.2017.1378650.

Hidalgo-Marí, T. (2017). De la maternidad al empoderamiento: una panorámica sobre la representación de la mujer en la ficción española. Revista Prisma Social, 2, 291-314.

Horting, Joseph (1983). Visual Literacy and Visual Thinking. In L. Burbank and D. Pett (Eds.), Contribution to the Study of Visual Literacy, (pp. 92-106). Bloomington: International Visual Literacy Association.

Hunt, Peter (2009). The World in Pictures. In S. Hallam (Ed.), Illustrated Children's Books, (pp. 8-26). London: Black Dog.

Isol. (2003). Secreto de familia. México: Fondo de Cultura Económica. 
Johnston-Ataata, Kate (2018). 'One of the Most Vulnerable Times in Your Life': Expectations and Emotional Experiences of Support in the Early Postnatal Period. In R. Kokanović, P.A. Michaels and K. Johnston-Ataat (Eds.), Paths to Parenthood, (pp. 187-214). London: Palgrave Macmillan.

Kaplan, Elizabeth. (2013). Motherhood and Representation: The Mother in Popular Culture and Melodrama. London: Routledge.

Kovač, Smiljana Narancîc (2017). Picturebooks and Narratology. In Bertina Kümmerling-Meibauer (Ed.), The Routledge Companion to Picturebooks, (pp. 409-419). London: Routledge.

Leaper, Campbell, and Friedman, Carly K. (2007). The Socialization of Gender. In J.E. Grusec and P.D. Hastings (Eds.), Handbook of Socialization: Theory and Research, (pp. 561-587). New York: The Guilford Press.

Lombardo, D.R. (2011). Identidad de género en personajes de ficción infantil y juvenil: hacia una ruptura de los estereotipos. Acciones e Investigaciones Sociales, 29, 173-200.

Lotero Osorio, Hernán, González, Isabel, Villa, Cristina \& Torres, Luz E. (2018). Afectividad y Apoyo Social Percibido en Mujeres Gestantes: un Análisis Comparativo. Revista Colombiana de Psicología, 27(2), 85-101. https://doi.org/10.15446/rcp.v27n2.65584.

Marsh, Rosalind (2012). New Mothers for a New Era? Images of Mothers and Daughters in Post-Soviet Prose in Historical and Cultural Perspective. Modern Language Review, 107(4), 1191-1219. https:// doi.org/10.5699/modelangrevi.107.4.1191.

Martin, James R.., and White, Peter R.R.. (2005). The Language of Evaluation: Appraisal in English. London: Palgrave Macmillan.

Martínez, Pilar, Carrasco, María José., Aza, Gonzalo, Blanco, Ángeles., and Espinar, Isabel (2011). Family Gender Roles and Guilt in Spanish Dual-Earner Families. Sex Roles, 65, 813-326. https://doi. org/10.1007/s11199-011-0031-4.

Martínez-Rodrigo, E., and Martínez-Cabeza, J. (2020). La figura materna en el cine de Pixar. Historia y Comunicación Social, 25(1), 35-44. https://doi.org/10.5209/hics.64587.

Martucci, Jessica (2015). Back to the Breast: Natural motherhood and Breastfeeding in America. Chicago: University of Chicago Press.

Miller, Alice. (1981). Prisoners of Childhood: The Drama of the Gifted Child and the Search for the True Self. New York: Basic Books.

Ministerio de Educación, Cultura y Deporte. (2017). Los libros infantiles y juveniles en España. Madrid. https://www.observatoriodelainfancia.es/ficherosoia/documentos/5414_d_informelij-2017.pdf.

Mellor, Mary. (2018). Feminism and Ecology. New York: Wiley.

Molina, J.A., and Montuenga, V.M. (2009). The motherhood wage penalty in Spain. Journal of Family and Economic Issues, 30(3), 237-251. https://doi.org/10.1007/s10834-009-9153-z.

Moya-Guijarro, A.J. (2014). A Multimodal Analysis of Picture Books for Children: A Systemic Functional Approach. London: Equinox.

Moya-Guijarro, A. J., \& Cañamares-Torrijos, C. (2020). Libros álbum que desafían los estereotipos de género y el concepto de familia tradicional. Ediciones de la Universidad de Castilla-La Mancha. Cuenca.

Moya-Guijarro, A.J., and Ventola, E. (2021). A Multimodal Approach to Challenging Gender Stereotypes in Children's Picture Books. London: Taylor \& Francis.

O’Halloran, K.L. (2008). Systemic Functional-Multimodal Discourse Analysis (SF-MDA): Constructing Ideational Meaning Using Language and Visual Imagery. Visual Communication, 7(4), 443-475. https://doi.org/10.1177/1470357208096210.

Oltra-Albiach, M.A., and Pardo-Coy, R.M. (2015). Family and Affective Models in Children's Literature. An Approach from the Texts for Early Readers at Valencian Schools. Procedia - Social and Behavioral Sciences, 178, 185-189.

O'Reilly, Andrea (Ed.). (2012). From Motherhood to Mothering: The Legacy of Adrienne Rich's of Woman Born. Albany: SUNY Press.

Oteíza, Teresa (2017). The Appraisal Framework and Discourse Analysis. In T. Bartlett and G. O’Grady (Eds.), The Routledge Handbook of Systemic Functional Linguistics, (pp. 457-472). London: Taylor $\&$ Francis.

Painter, C. (2017) Multimodal Analysis of Picturebooks. In B. Kümmerling-Meibauer (Ed.), The Routledge Companion to Picturebooks (pp. 420-428). Routledge.

Podnieks, Elisabeth, and O'Reilly, Andrea. (2010). Textual Mothers/Maternal Texts Motherhood in Contemporary Women's Literatures. Waterloo: Wilfred Laurier University Press. 
Preisner, Klaus, Neuberger, Franz, Bertogg, Ariane, and Schaub, Julia (2020). Closing the Happiness Gap: The Decline of Gendered Parenthood Norms and the Increase in Parental Life Satisfaction. Gender \&amp; Society, 34(1), 31-55. https://doi.org/10.1177/0891243219869365.

Prinds, Christina, Mogensen, Ole, Hvidt, Niels, and Bliddal, Mette (2018). First Child's Impact on Parental Relationship: An Existential Perspective. BMC Pregnancy and Childbirth, 18, 157. https://doi. org/10.1186/s12884-018-1802-5.

Puleo, Alicia (2002). Feminismo y ecología. El Ecologísta, 31, 36-39.

Rich, Adrienne. (1976). Of Woman Born: Motherhood as Experience and Institution. New York: WW Norton \& Company.

Ross, Lynda. (2017). Interrogating Motherhood. Athabasca: AU Press.

Rottenberg, B. (2017). A Bibliotherapeutic Reading of Alice in Wonder-Mother-Blogging Land. Journal of Poetry Therapy, 30(3), 189-199. https://doi.org/10.1080/08893675.2017.1328865.

Rowe, Karen E. (1979). Feminism and Fairy Tales. Women's Studies: an Interdisciplinary Journal, 6(3), 237-257. https://doi.org/10.1080/00497878.1979.9978487.

Ruiz Johnson, Mariana. (2013). Mamá. Pontevedra: Kalandraka.

Santamaría-García, Carmen (2021). A Semiotic and Multimodal Analysis of Interactive Relations in Picture Books That Challenge Female Gender Stereotypes. In A.J. Moya-Guijarro and E. Ventola (Eds.), Multimodal Approach to Challenging Gender Stereotypes in Children's Picture Books, (pp. 144-163). London: Routledge.

Sau, Victoria. (1995). El vacío de la maternidad: madre no hay más que ninguna. Barcelona: Icaria Editorial.

Sau, Victoria. (2001). Diccionario ideológico feminista. Barcelona: Icaria Editorial.

Sendón, Victoria. (2002). Marcar las diferencias. Discursos feministas ante un nuevo siglo. Barcelona: Icaria Editorial.

Senís Fernández, Juan (2014). El álbum ilustrado como agente de educación artístico-literaria y de género el caso de Mamá, de Mariana Ruíz Johnson. Dossiers Feministes, 19, 115-133.

Servant, Stéphane \& Houdart, Emmanuelle. (2016). Madre entre el sol y la noche. Trans. Luisa Antolín Villota. Barcelona: Libros del zorro rojo.

Showalter, Elaine. (1978/1999). A Literature of Their Own: British Women Novelists from Brontë to Lessing. Princeton: Princeton University Press.

Skorinko, Jeanine LM., Rodriguez, Incollingo, Angela, C., and Doyle, James K. (2020). Overlapping Stigmas of Pregnancy, Motherhood, and Weight: Policy Implications for Employment and Higher Education. Policy Insights from the Behavioral and Brain Sciences, 7(2), 123-131. https://doi.org/ $10.1177 / 2372732220943233$.

Stephens, Julie. (2012). Confronting Postmaternal Thinking: Feminism, Memory, and Care. New York: Columbia University Press.

Strouse, G.A., Nyhout, A., and Ganea, P.A. (2018). The Role of Book Features in Young Children's Transfer of Information from Picture Books to Real-World Contexts. Frontiers in Psychology, https://doi.org/10.3389/fpsyg.2018.00050.

Sunderland, J. (2006). 'Parenting' or 'Mothering'? The Case of Modern Childcare Magazines. Discourse \&amp; Society, 17(4), 503-528. https://doi.org/10.1177/0957926506063126.

Taboada, Bea, and Padrón, Dani. (2020). A veces mamá tiene truenos en la cabeza. Alzira: Algar.

Tello, Jimena. (2017). Mamá al galope. Barcelona: Flamboyant.

Tian, Ping (2010). Playing with "Femininity": An Intermodal Analysis of the Bilingual Picture Book The Ballad of Mulan. In Monika Bednarek and James R. Martin (Eds.), New Discourse on Language: Functional Perspectives on Multimodality, Identity and Affiliation, (pp. 134-162). London: Continuum.

Turin, Adela. (1995). Los cuentos siguen contando. Algunas reflexiones sobre los estereotipos (Vol. 20). Madrid: Horas y horas.

Veazey, L.W. (2018). The Turbulent Emotions of Early Parenthood. In R. Kokanović, P.A. Michaels and K. Johnston-Ataata (Eds.), Paths to Parenthood: Emotions on the Journey Through Pregnancy, Childbirth, and Early Parenting, (pp. 119-143). New York: Springer.

Vega, S.M., Barredo, D., \& Merchán, A. (2019). Roles de género en los contenidos publicitarios de las revistas femeninas de alta gama españolas, su asociación con los patrones femeninos corporales restrictivos y la percepción que tiene la mujer real de este fenómeno. Estudios sobre el mensaje periodístico, 25(3). https://doi.org/10.5209/esmp.67009.

Vintró, N.M. (2008). Sexismo en la literatura infantil. CLIJ: Cuadernos De Literatura Infantil y Juvenil, 21(217), 21-27. 
Wallworth, Giorgia. (2018). Traversing the boundaries of the New Momism: Challenging the "good" mother myth. PhD thesis, Department of Gender and Cultural Studies, University of Sydney.

Zivoder, Ivana, Martic-Biocina, Sanja, Veronek, Jurica, Ursulin-Trstenjak, Natalija, Melita, Sajko, and Paukovic, Marija (2019). Mental Disorders/Difficulties in the Postpartum Period. Psychiatr Danub, 31(Suppl 3), 338-344.

Publisher's Note Springer Nature remains neutral with regard to jurisdictional claims in published maps and institutional affiliations.

\section{Authors and Affiliations}

\section{Giulia De Sarlo $^{1}$ (D) Elena Guichot-Muñoz ${ }^{1}$ (D) Coral I. Hunt-Gómez ${ }^{1}$}

Elena Guichot-Muñoz

eguichot1@us.es

Giulia De Sarlo

gdesarlo@us.es

Coral I. Hunt-Gómez

coralhuntg@us.es

1 Department of Language and Literature Education, University of Seville, Seville, Spain 